\title{
On recent (2008-2012) stratospheric aerosols observed by lidar over Japan
}

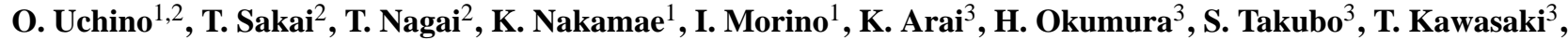 \\ Y. Mano ${ }^{2}$, T. Matsunaga ${ }^{1}$, and T. Yokota ${ }^{1}$ \\ ${ }^{1}$ National Institute for Environmental Studies, 16-2 Onogawa, Tsukuba, Ibaraki 305-8506, Japan \\ ${ }^{2}$ Meteorological Research Institute, 1-1 Nagamine, Tsukuba, Ibaraki 305-0052, Japan \\ ${ }^{3}$ Saga University, 1 Honjou, Saga, Saga 840-8502, Japan
}

Correspondence to: O. Uchino (uchino.osamu@nies.go.jp)

Received: 20 July 2012 - Published in Atmos. Chem. Phys. Discuss.: 3 September 2012

Revised: 20 November 2012 - Accepted: 2 December 2012 - Published: 17 December 2012

\begin{abstract}
An increase in stratospheric aerosols caused by the volcanic eruption of Mt. Nabro $\left(13.37^{\circ} \mathrm{N}, 41.70^{\circ} \mathrm{E}\right)$ on 12 June 2011 was detected by lidar at Tsukuba $\left(36.05^{\circ} \mathrm{N}\right.$, $\left.140.13^{\circ} \mathrm{E}\right)$ and Saga $\left(33.24^{\circ} \mathrm{N}, 130.29^{\circ} \mathrm{E}\right)$ in Japan. The maximum backscattering ratios at a wavelength of $532 \mathrm{~nm}$ were 2.0 at $17.0 \mathrm{~km}$ on 10 July 2011 at Tsukuba and 3.6 at $18.2 \mathrm{~km}$ on 23 June 2011 at Saga. The maximum integrated backscattering coefficients (IBCs) at $532 \mathrm{~nm}$ above the first tropopause height were $4.18 \times 10^{-4} \mathrm{sr}^{-1}$ on 11 February 2012 at Tsukuba and $4.19 \times 10^{-4} \mathrm{sr}^{-1}$ on 23 June 2011 at Saga, respectively.

A time series of lidar observational results at Tsukuba have also been reported from January 2008 through May 2012. Increases in stratospheric aerosols were observed after the volcanic eruptions of Mt. Kasatochi $\left(52.18^{\circ} \mathrm{N}, 175.51^{\circ} \mathrm{E}\right)$ in August 2008 and Mt. Sarychev Peak (48.09 $\left.{ }^{\circ} \mathrm{N}, 153.20^{\circ} \mathrm{E}\right)$ in June 2009. The yearly averaged IBCs at Tsukuba were $2.54 \times 10^{-4} \mathrm{sr}^{-1}, 2.48 \times 10^{-4} \mathrm{sr}^{-1}, 2.45 \times 10^{-4} \mathrm{sr}^{-1}$, and $2.20 \times 10^{-4} \mathrm{sr}^{-1}$ for 2008, 2009, 2010, and 2011, respectively. These values were about twice the IBC background level $\left(1.21 \times 10^{-4} \mathrm{sr}^{-1}\right)$ from 1997 to 2001 at Tsukuba. We briefly discuss the influence of the increased aerosols on climate and the implications for analysis of satellite data.
\end{abstract}

\section{Introduction}

Stratospheric aerosols play important roles in climate regulation and atmospheric chemistry. The effect of the aerosols produced by the Pinatubo eruption is a good example. The volcanic eruption of Mt. Pinatubo $\left(15.14^{\circ} \mathrm{N}, 120.35^{\circ} \mathrm{E}\right)$ on 15 June 1991 injected huge amounts of $\mathrm{SO}_{2}$ and ash into the stratosphere. The Volcanic Explosivity Index (VEI) was 6 (Smithsonian Institution, 2012). The eruption injected into the stratosphere an amount of $\mathrm{SO}_{2}$ estimated to be about $20 \mathrm{Tg}$, almost three times the input from the 1982 El Chichón eruption (Bluth et al., 1992). The injected $\mathrm{SO}_{2}$ was oxidized to sulfuric acid particles through homogeneous nucleation (Wu et al., 1994). Read et al. (1993) estimated the e-folding decay time of $\mathrm{SO}_{2}$ to be 33 days. The Pinatubo aerosol particles were effectively transported from tropical regions into northern mid-latitudes during fall through spring with planetary wave activity. The maximum backscattering ratio observed at a wavelength of $532 \mathrm{~nm}$ was 14.1 at $22.7 \mathrm{~km}$ over Tsukuba $\left(36.05^{\circ} \mathrm{N}, 140.13^{\circ} \mathrm{E}\right)$ on 29 November 1991 . The maximum value of the integrated backscattering coefficient (IBC) above the first tropopause height was $7.1 \times 10^{-3} \mathrm{sr}^{-1}$ over Tsukuba on 22 February 1992 (Uchino et al., 1995).

The stratospheric aerosol surface area increased after the Pinatubo eruption (Jäger et al., 1995; Uchino, 1996), and severe ozone loss occurred in 1992 and 1993 because of heterogeneous chemical reactions on aerosol surfaces in the presence of high concentrations of anthropogenic chlorine and bromine (Hofmann et al., 1994; Kondo et al., 1995; WMO, 1995; Solomon et al., 1996).

The maximum net (thermal minus solar) radiative forcing from the 1991 Pinatubo eruption was about $-3 \mathrm{~W} \mathrm{~m}^{-2}$ (Hansen et al., 2005). Global lower stratospheric (30$100 \mathrm{hPa}$ ) temperature anomalies increased after the eruption, and global tropospheric $(300-850 \mathrm{hPa})$ temperature 
anomalies decreased after the eruption in spite of the warm ENSO episode in 1991/1992 (Kawamata et al., 1992). Global tropospheric temperatures generally increase after a warm ENSO episode. For two years following major volcanic eruptions, global mean surface temperatures decrease by $0.1-$ $0.2^{\circ} \mathrm{C}$, and mean surface temperatures in the latitude band $30-60{ }^{\circ} \mathrm{N}$ by $0.3{ }^{\circ} \mathrm{C}$ during the summer (Robock and Mao, 1995). A model simulation of the effects of the 1991 Pinatubo eruption predicted a decrease in the global surface temperature by about $0.5^{\circ} \mathrm{C}$ in September, October, and November 1992, in agreement with observations during that time (Hansen et al., 1996). In contrast, warm surface temperatures were recorded over Europe, Siberia, and North America, while cooling occurred over western Asia in the winters after the three major volcanic eruptions of Mt. Agung in 1963, Mt. El Chichón in 1982, and Mt. Pinatubo in 1991 (Kodera, 1994).

The IBC of the Pinatubo aerosols decayed with e-folding times of 1.14, 1.29, and 1.37 years over Tsukuba and Naha $\left(26.21^{\circ} \mathrm{N}, 127.69^{\circ} \mathrm{E}\right)$ in Japan and over Lauder $\left(45.04^{\circ} \mathrm{S}\right.$, $\left.169.68^{\circ} \mathrm{E}\right)$ in New Zealand, respectively. The IBC over Tsukuba varied in a clearly seasonal manner, with a maximum in winter and early spring and a minimum in summer. The IBC over Tsukuba reached the background level in October 1997 (Nagai et al., 2010).

Since about 2000, an increase of 4-7\% per year in the IBC has been detected within the $20-30 \mathrm{~km}$ altitude range at both Mauna Loa, Hawaii $\left(19^{\circ} \mathrm{N}\right)$, and Boulder, Colorado $\left(40^{\circ} \mathrm{N}\right)$, and the increase could be caused by anthropogenic emission of $\mathrm{SO}_{2}$ (Hofmann et al., 2009). Likewise, after the IBC over Lauder reached a minimum between 1997 and 2000, it increased $3.8 \%$ per year from 2000 to 2009 (Nagai et al., 2010). Based on some satellite data, the stratospheric aerosol optical thickness (AOT) increased after 2000 as the result of a series of moderate but increasingly intense volcanic eruptions (Vernier et al., 2011). In fact, increases in stratospheric aerosols were reported from lidar observations after the volcanic eruptions of Mt. Kasatochi $\left(52.18^{\circ} \mathrm{N}, 175.51^{\circ} \mathrm{E}\right)$ in August 2008 (Bitar et al., 2010) and Mt. Sarychev Peak $\left(48.09^{\circ} \mathrm{N}, 153.20^{\circ} \mathrm{E}\right)$ in June 2009 (Uchino et al., 2010; O'Neill et al., 2012).

In this paper we report observations of stratospheric aerosols in the year following the volcanic eruption of Mt. Nabro $\left(13.37^{\circ} \mathrm{N}, 41.70^{\circ} \mathrm{E}\right)$ in June 2011 at two lidar sites in Tsukuba and Saga $\left(33.24^{\circ} \mathrm{N}, 130.29^{\circ} \mathrm{E}\right)$, Japan. These two lidar sites are prioritized validation sites for studying the influence of aerosols and thin cirrus clouds on columnaveraged dry air mole fractions of carbon dioxide $\left(\mathrm{XCO}_{2}\right)$ and methane $\left(\mathrm{XCH}_{4}\right)$ derived from data collected by the Greenhouse gases Observing SATellite (GOSAT) (Yoshida et al., 2011; Morino et al., 2011; Uchino et al., 2012). GOSAT was launched on 23 January 2009. At Saga, lidar observations started in March 2010. Next, we present lidar observational results from January 2008 to May 2012 over Tsukuba. Finally we discuss briefly the influence of the recent increase in stratospheric aerosols on GOSAT products and compare their impact on climate to the 1991 Pinatubo eruption.

\section{Lidar instruments and data analysis}

The compact lidars installed at Tsukuba and Saga were twowavelength polarization lidar systems (Table 1), the fundamental and second harmonic having wavelengths of $1064 \mathrm{~nm}$ $\left(\lambda_{1}\right)$ and $532 \mathrm{~nm}\left(\lambda_{2}\right)$, respectively. Backscattered photons from the atmosphere were collected by one or two Schmidt Cassegrain type telescopes. A polarizer divided photons at $\lambda_{2}$ into components parallel $(\mathrm{P})$ and perpendicular (S) to the transmitted laser polarization plane. The received photons were converted to electrical signals by an avalanche photodiode (APD, C30956EH) at $\lambda_{1}$. At $\lambda_{2}$, three or five photomultiplier tubes (PMTs, R3234-01) were used to simultaneously obtain high-dynamic-range signals from near the surface to an altitude of $\sim 40 \mathrm{~km}$. Transient recorders used a 12bit analog-to-digital (A/D) converter and a photon counter (TR 20-160) to process the output signals of the APD and PMTs. Because the APD signals were noisy above altitudes of about $20-25 \mathrm{~km}$, we used only lidar data at $\lambda_{2}$ for stratospheric aerosols.

The backscattering ratio $R$ is defined as

$R=(B R+B A) / B R$,

where $B R$ and $B A$ are the molecular and aerosol backscattering coefficients, respectively. We derived backscattering ratio profiles with an inversion method (Fernald, 1984). The lidar ratio $S$ (particle extinction to backscatter ratio) is dependent on the stratospheric aerosol size distribution and refractive index, and equalled $20-60 \mathrm{sr}$ at $532 \mathrm{~nm}$ during 1979-1999 (Jäger and Deshler, 2002, 2003). The lidar ratio was small just after the major volcanic eruptions of El Chichon in 1982 and Pinatubo in 1991, but it equals about $50 \mathrm{sr}$ for usual stratospheric aerosols. We assumed that the lidar ratio equalled $50 \mathrm{sr}$ for the moderate volcanic eruptions of Kasatochi in 2008, Sarychev in June 2009, and Nabro in June 2011. We used the nearest operational radiosonde data to calculate the atmospheric molecular density. The radiosonde sounding stations are Tateno $\left(36.05^{\circ} \mathrm{N}, 140.13^{\circ} \mathrm{E}\right)$ and Fukuoka $\left(33.58^{\circ} \mathrm{N}, 130.38^{\circ} \mathrm{E}\right)$ for Tsukuba and Saga, respectively. We used the 1976 US Standard Atmosphere model above balloon observational altitudes (US Committee on Extension of the Standard Atmosphere, 1976). The lidar backscattered signal was interactively normalized to unity around $25-33 \mathrm{~km}$, where aerosol-free conditions could be assumed.

We obtained IBCs by summing up $B A$ s from the first tropopause height to an altitude of $33 \mathrm{~km}$. When cirrus clouds appeared above the tropopause, we set the lower limit of the integration to just above the altitude of the cirrus clouds. If the signal-to-noise ratio at higher altitudes was not good enough, the upper limit of the integration was decreased to 
Table 1. Characteristics of two-wavelength polarization lidar systems at Tsukuba and Saga.

\begin{tabular}{|c|c|c|c|c|}
\hline Station & \multicolumn{2}{|c|}{ Tsukuba } & \multicolumn{2}{|c|}{ Saga } \\
\hline \multicolumn{5}{|l|}{ Transmitter } \\
\hline Laser & \multicolumn{2}{|c|}{ Nd:YAG } & \multicolumn{2}{|c|}{ Nd:YAG } \\
\hline Wavelength & $532 \mathrm{~nm}$ & $1064 \mathrm{~nm}$ & $532 \mathrm{~nm}$ & $1064 \mathrm{~nm}$ \\
\hline Pulse Energy & $140 \mathrm{~mJ}$ & $230 \mathrm{~mJ}$ & $130 \mathrm{~mJ}$ & $130 \mathrm{~mJ}$ \\
\hline Pulse Repetition & \multicolumn{2}{|c|}{$20 \mathrm{~Hz}$} & \multicolumn{2}{|c|}{$10 \mathrm{~Hz}$} \\
\hline Beam Divergence & $0.2 \mathrm{mrad}$ & $0.2 \mathrm{mrad}$ & $0.2 \mathrm{mrad}$ & $0.2 \mathrm{mrad}$ \\
\hline \multicolumn{5}{|l|}{ Receiver } \\
\hline Telescope Type & \multicolumn{2}{|c|}{ Schmidt Cassegrain } & \multicolumn{2}{|c|}{ Schmidt Cassegrain } \\
\hline Telescope Diameter & \multicolumn{2}{|c|}{$35.5 \mathrm{~cm}$ (Far) $20.0 \mathrm{~cm}$ (Near) } & \multicolumn{2}{|c|}{$30.5 \mathrm{~cm}$} \\
\hline Field of View & \multicolumn{2}{|c|}{$1.0 \mathrm{mrad}$} & \multicolumn{2}{|c|}{$1.0 \mathrm{mrad}$} \\
\hline Polarization & $\mathrm{P}$ and $\mathrm{S}$ & None & $\mathrm{P}$ and $\mathrm{S}$ & None \\
\hline Number of Channels & 5 & 2 & 3 & 1 \\
\hline Vertical Resolution & \multicolumn{2}{|c|}{$7.5 \mathrm{~m}($ minimum $)$} & \multicolumn{2}{|c|}{$7.5 \mathrm{~m}($ minimum $)$} \\
\hline Detectors & PMT (R3234-01) & (C30956EH) & PMT (R3234-01) & (C30956EH) \\
\hline Signal Processing & \multicolumn{2}{|c|}{12 bit $\mathrm{A} / \mathrm{D}$ and Photon Counting } & \multicolumn{2}{|c|}{12 bit $\mathrm{A} / \mathrm{D}$ and Photon Counting } \\
\hline
\end{tabular}

a lower altitude where the signal-to-noise ratio was acceptable (Nagai et al., 2010). The IBC varies approximately by $\pm 10 \%$ for change of $S$ by $50 \pm 20$.

The total linear depolarization ratio $(\delta)$ is defined as

$\delta=S /(P+S) \cdot 100(\%)$,

where $P$ and $S$ are the parallel and perpendicular components of the backscattered signals. The particle depolarization $\delta_{\mathrm{p}}$ is obtained from the equation

$\delta_{\mathrm{p}}=\left(\delta \cdot R-\delta_{\mathrm{m}}\right) /(R-1) \cdot 100(\%)$,

where $\delta_{\mathrm{m}}$ is the depolarization ratio of atmospheric molecules (Sakai et al., 2003). We adopted a vertical resolution of $150 \mathrm{~m}$ in the following analysis.

\section{Observational results over Tsukuba and Saga after the 2011 Nabro eruption}

The Nabro volcano erupted in Eritrea on 12 June 2011. The volcanic ash was detected at 10:45 UTC on 13 June by the Moderate Resolution Imaging Spectrometer (MODIS) on the Aqua satellite (NASA, 2012). The first $\mathrm{SO}_{2}$ associated with the eruption was measured on 12 June by the Infrared Atmospheric Sounding Interferometer (IASI), and continued emissions were observed for weeks. The total mass of $\mathrm{SO}_{2}$ measured by IASI was on the order of $1.5 \mathrm{Tg}$ (Clarisse et al., 2012). Over Tsukuba, new aerosol layers with double peaks were observed on 20 June 2011 about 8 days after the eruption (Fig. 1). The peak values of $R$ were 1.58 and 1.32 at 16.0 and $16.4 \mathrm{~km}$, respectively. The values of $\delta$ and $\delta_{\mathrm{p}}$ were $1.25 \%$ and $3.4 \%$ at $16.0 \mathrm{~km}$, respectively and $1.94 \%$ and $7.9 \%$ at $16.4 \mathrm{~km}$, respectively. Non-spherical ash particles were probably included in the layers with sulfuric acid particles that were produced from $\mathrm{SO}_{2}$ through chemical reactions. Non-spherical particles were also present in the lower region of the aerosol layer on 12 September $\left(\delta_{\mathrm{p}}=4.7 \%\right.$ at $17.0 \mathrm{~km})$. The maximum backscattering ratio $\left(R_{\max }\right)$ of 2.0 was observed at $17.0 \mathrm{~km}$ on 10 July 2011 .

Over Saga, new stratospheric aerosols with double peaks were detected on 23 June 2011 (Fig. 2). Peak values of $R$ were 2.27 and 3.68 at 17.2 and $18.2 \mathrm{~km}$, respectively. The values of $\delta_{\mathrm{p}}$ were $0.2 \%$ and $0.8 \%$ at 17.2 and $18.2 \mathrm{~km}$, respectively. In this case, aerosols were probably composed of spherical particles because $\delta_{\mathrm{p}}$ was very small. However, some non-spherical particles were also seen in the lower regions of the layers on 29 August $\left(\delta_{\mathrm{p}}=3.6 \%\right.$ at $\left.16.6 \mathrm{~km}\right)$ and 24 September $\left(\delta_{\mathrm{p}}=4.0 \%\right.$ at $\left.16.6 \mathrm{~km}\right)$. In the 1991 Pinatubo eruption, non-spherical particles were present in the lower stratosphere for at least six months (Nagai et al., 1993) because the Pinatubo ash particles were injected into higher altitudes than the Nabro ash particles.

We used the National Centers for Environmental Prediction (NCEP)/National Center for Atmospheric Research (NCAR) reanalysis data (Kalnay et al., 1996) and the Meteorological Data Explorer (METEX), developed by Dr. Jiye Zeng at the Centre for Global Environmental Research (CGER) in the National Institute for Environmental Studies (NIES) to calculate isentropic forward trajectories of 36 air parcels that originated from a square of \pm 1 degree surrounding the Nabro volcano at altitudes of 16,17 , and $18 \mathrm{~km}$. The calculation simulated the trajectories of the air parcels for ten days beginning at 23:00 UTC on 12 June 2011 (Fig. 3). Only some of the parcels that originated at $17 \mathrm{~km}$ (potential temperature of $384.3 \mathrm{~K}$ ) over Mt. Nabro were transported to $\sim 16 \mathrm{~km}$ over Tsukuba on 20 June, a result that was consistent with lidar observations as shown in Fig. 1. The air parcels 


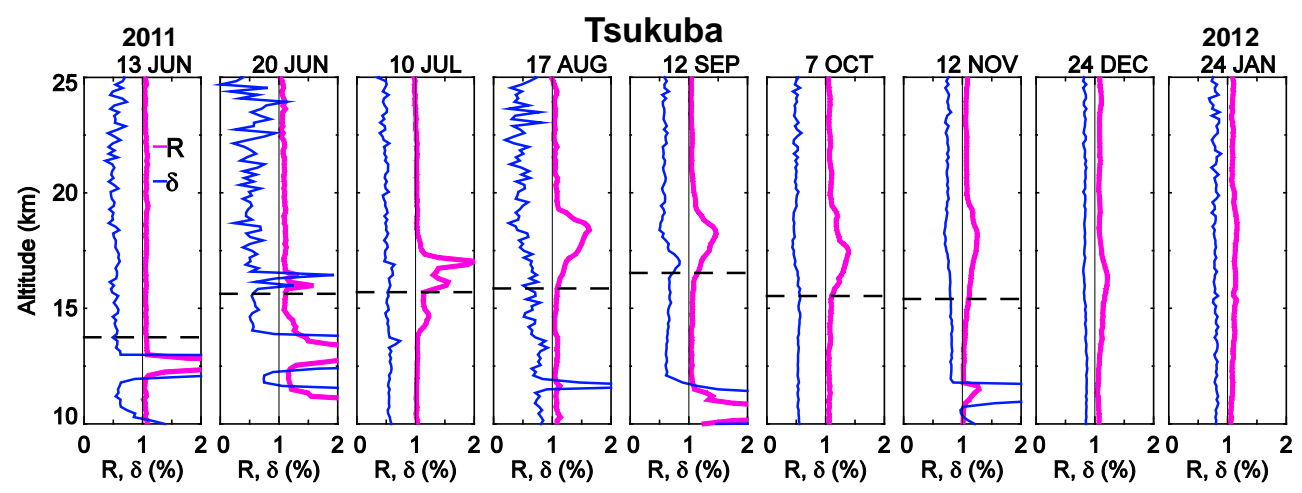

Fig. 1. Vertical profiles of the backscattering ratio $R$ (pink line) and total depolarization ratio $\delta(\%)$ (blue line) at $\lambda_{2}=532 \mathrm{~nm}$ over Tsukuba from June 2011 through January 2012. Horizontal dashed lines show the first local tropopause heights. Large values of $R$ and $\delta$ below tropopause heights are caused by cirrus clouds.

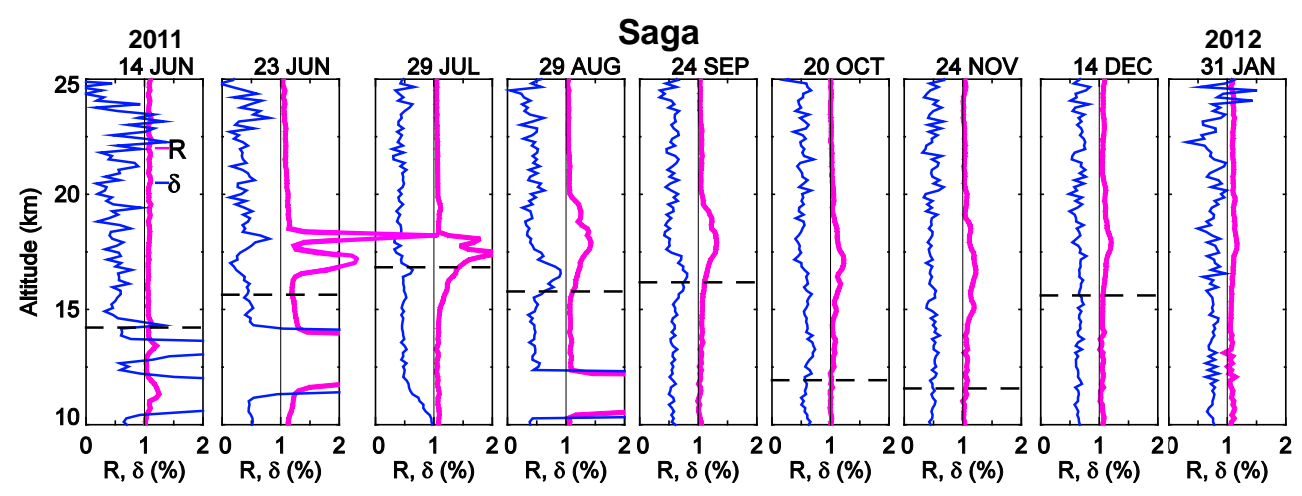

Fig. 2. The same as Fig. 1 except for Saga.

moved eastward around the northern part of the Tibetan highpressure ridge (Fig. 4). The composite image of maximum observed $\mathrm{SO}_{2}$ columns in Fig. 12 of Clarisse et al. (2012) also shows this feature. We confirmed that the backward trajectory of an air parcel from Tsukuba $(16 \mathrm{~km}, 13: 00$ UT on 20 June 2011$)$ arrived at a point $\left(16.7 \mathrm{~km}, 14.62^{\circ} \mathrm{N}, 33.42^{\circ} \mathrm{E}\right)$ near Mt. Nabro on 23:00 UTC on 12 June. Therefore, new aerosol layers observed over Japan in late June 2011 could have originated from the Nabro eruption on 12 June. The Nabro particles were also observed by the Optical Spectrograph and InfraRed Imaging System (OSIRIS) and those particles were transported to the middle and higher latitudes (Bourassa et al., 2012).

Figure 5 shows the time variation of IBC (pink solid diamond) and first tropopause height (blue open circle) over Tsukuba (upper panel) and Saga (lower panel) from June 2011 to May 2012. Over Tsukuba, the largest values of the IBC were $\sim 3.0 \times 10^{-4} \mathrm{sr}^{-1}$ in summer and $\sim 4.0 \times 10^{-4} \mathrm{sr}^{-1}$ in winter. The maximum IBC was $4.18 \times 10^{-4} \mathrm{sr}^{-1}$ on 11 February 2012. In general the IBC increased when the tropopause height decreased. Over Saga, the maximum IBC was $4.19 \times 10^{-4} \mathrm{sr}^{-1}$ on 23 June 2011, the day of the first arrival of the Nabro aerosols. Then the
IBC decreased quickly within a week, but increased again in late July. From Fig. 5, it is supposed that the Nabro particles were distributed over Japan non-uniformly during June through early July, and almost uniformly after late July 2011. The IBC then decreased gradually from August to December 2011 , except for a brief peak larger than $\sim 3.5 \times 10^{-4} \mathrm{sr}^{-1}$ on 24 and 25 November. The IBC increased again in January and February 2012. The mean value of the IBC over Saga was $1.86 \times 10^{-4} \mathrm{sr}^{-1}$ from June 2011 to May 2012 .

\section{Time variation of stratospheric aerosols over Tsukuba from January 2008 to May 2012 and discussion}

Mt. Kasatochi in the Aleutian Islands erupted on 7 and $8 \mathrm{Au}-$ gust 2008 with a VEI of 4 (Smithsonian Institution, 2012). The Ozone Monitoring Instrument (OMI) on NASA's Aura satellite tracked a dense cloud that contained about $1.5 \mathrm{Tg}$ of $\mathrm{SO}_{2}$. The $\mathrm{SO}_{2}$ clouds spread over the Arctic and eastward across the United States and Canada (NASA, 2012). Over Halifax $\left(44.64^{\circ} \mathrm{N}, 63.59^{\circ} \mathrm{W}\right)$ in Canada, aerosols from the volcanic plume were detected with lidar one week after the eruption and for the next four months thereafter (Bitar et al., 

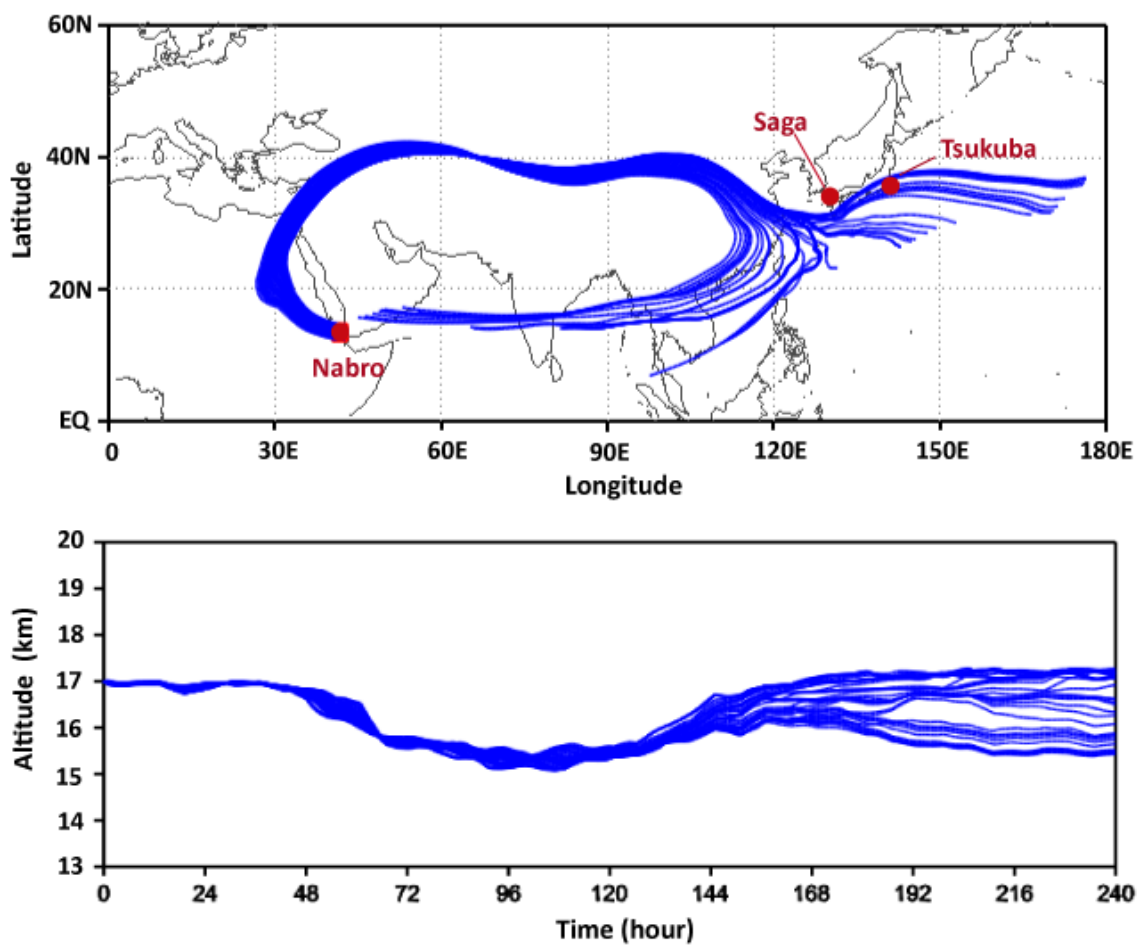

Fig. 3. Horizontal (upper panel) and vertical (lower panel, versus time) projections of isentropic forward trajectories of air parcels initially at an altitude of $17 \mathrm{~km}$ over Mt. Nabro (red square). The trajectories were calculated for ten days from 23:00 UTC on 12 June 2011. Tsukuba and Saga lidar sites are indicated by red circles in the upper panel.

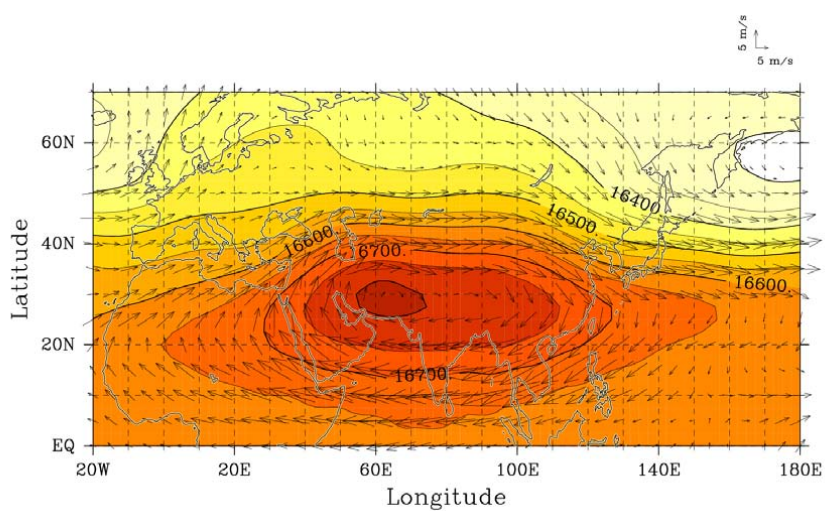

Fig. 4. Monthly means of geopotential height $(\mathrm{m})$ and wind $\left(\mathrm{m} \mathrm{s}^{-1}\right)$ on $100 \mathrm{hPa}$ in June 2011 calculated from NCEP/NCAR reanalysis data. The wind speed scale is shown above the right side of the figure.

2010). Over Tsukuba, stratospheric aerosols produced from those $\mathrm{SO}_{2}$ gases were detected at $17.3 \mathrm{~km}$ and $16.0 \mathrm{~km}$ on 2 September and at $18.7 \mathrm{~km}$ and $17.3 \mathrm{~km}$ on 16 September, about one month after the eruption (Fig. 6). Clear peaks of $R$ were also seen on 4 and 21 October, but subsequent peaks were ambiguous. Obvious stratospheric aerosols from the Kasatochi eruption were also observed from 10 September to 13 October over Ryori $\left(39.03^{\circ} \mathrm{N}, 141.82^{\circ} \mathrm{E}\right)($ Sakashita et al., 2009).

Mt. Sarychev Peak erupted on 12 June 2009 with a VEI of 4 (Smithsonian Institution, 2012). A new aerosol layer was observed at $20.6 \mathrm{~km}$ on 25 June over Tsukuba (Fig. 7). The peak value of $R$ was 3.5. Because $\delta_{\mathrm{p}}$ was $7 \%$, some non-spherical ash particles were probably included in the layer. Backward trajectory analysis revealed that aerosols in the layer were transported to Tsukuba by easterly winds. Aerosols observed around $14-15 \mathrm{~km}$ on 5 July were transported by westerly winds. Enhanced aerosol layers were also observed over three other lidar sites in Japan (Uchino et al., 2010). Mt. Merapi ( $\left.7.54^{\circ} \mathrm{S}, 110.44^{\circ} \mathrm{E}\right)$, one of Indonesia's most active volcanoes, erupted on 26 October 2010 with a VEI of 4 (Smithsonian, 2012). Shortly thereafter we did not observe enhanced stratospheric aerosols that originated from the Merapi eruption, because noticeable peaks of $R$ were not detected. However, the enhancement of IBC in winter 2010 and spring 2011 could be partly due to the Merapi eruption.

The temporal variation of the IBC over Tsukuba from January 2008 through May 2012 is shown in Fig. 8, with the exception of about two months in 2011 after the Tohoku earthquake off the Pacific Coast of Japan, when lidar data were not obtained. The earthquake occurred in the northern part of Japan on 11 March 2011. After the decay of the Pinatubo aerosols, stratospheric aerosols were at background levels 

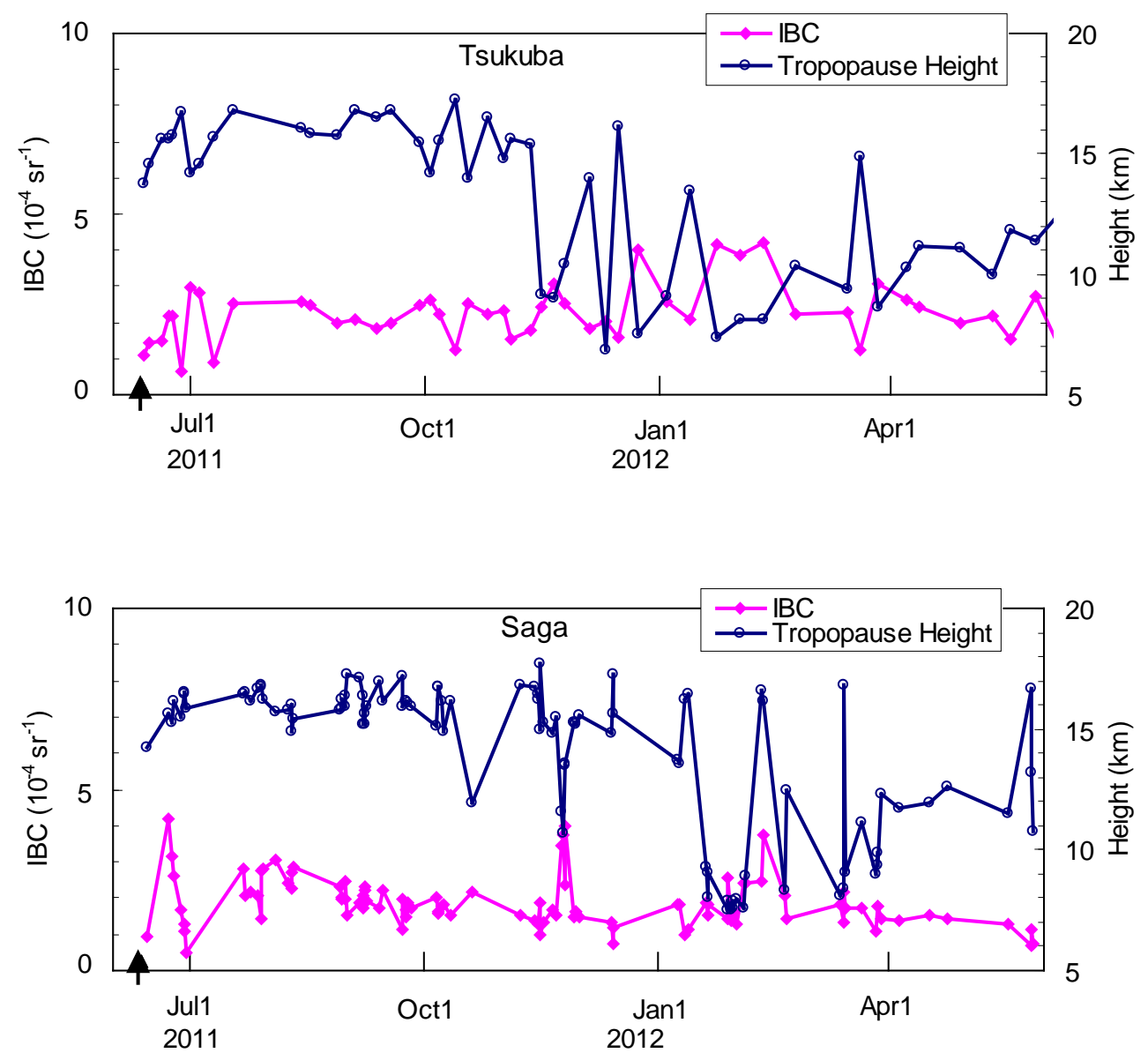

Fig. 5. Temporal variation of the integrated backscattering coefficient (IBC) from the first tropopause to an altitude of $33 \mathrm{~km}$ (pink solid diamond) and first tropopause height (blue open circle) over Tsukuba (upper panel) and Saga (lower panel) from June 2011 to May 2012.
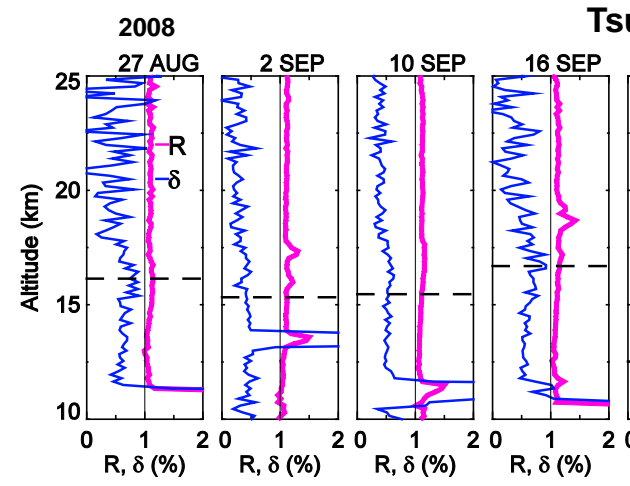

Tsukuba
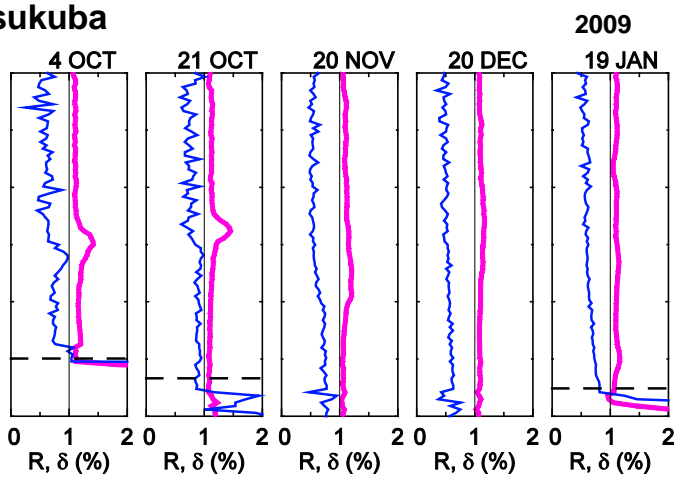

Fig. 6. Profiles similar to Fig. 1 over Tsukuba from August 2008 to January 2009 after the 2008 Kasatochi eruption.

from October 1997 to September 2001 at Tsukuba (Nagai et al., 2010). The annual mean of the IBC for the background aerosols was $1.21 \times 10^{-4} \mathrm{sr}^{-1}$. Based on the fit of a sinusoidal function to the data, the amplitude of the seasonal variation was $6.84 \times 10^{-5} \mathrm{sr}^{-1}$, with a maximum in February and minimum in August (Fig. 8). According to Deshler et al. (2006), no long-term change in the background concentration of stratospheric aerosols has occurred over the period 1972-2004, and therefore the background level of the IBC observed over Tsukuba from October 1997 to September 2001 might be similar to the background levels during the period 1972-2004. 

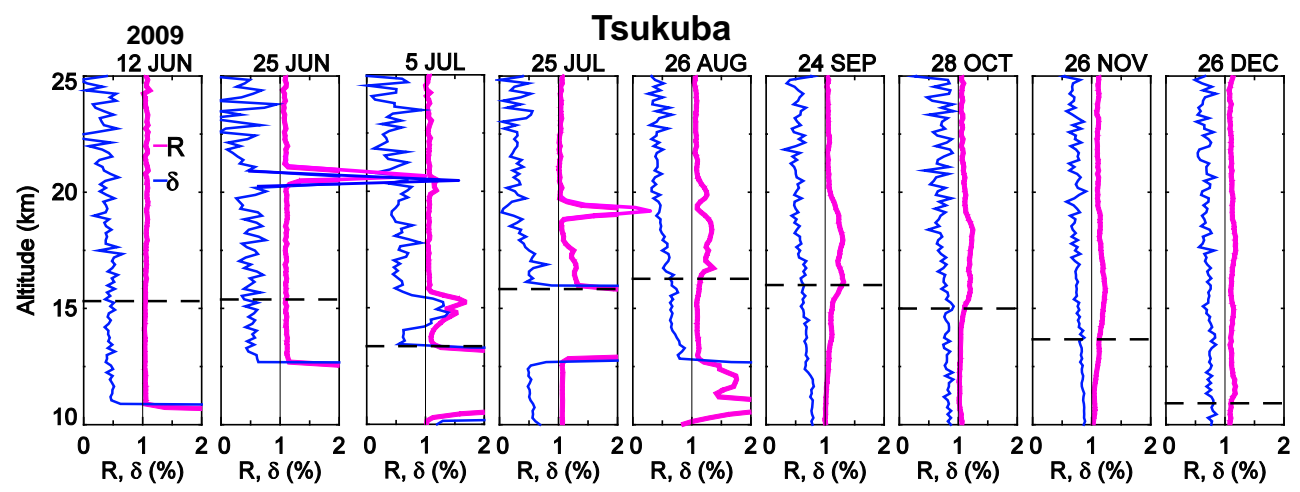

Fig. 7. Profiles similar to Fig. 1 over Tsukuba from June to December 2009 after the 2009 Sarychev eruption.

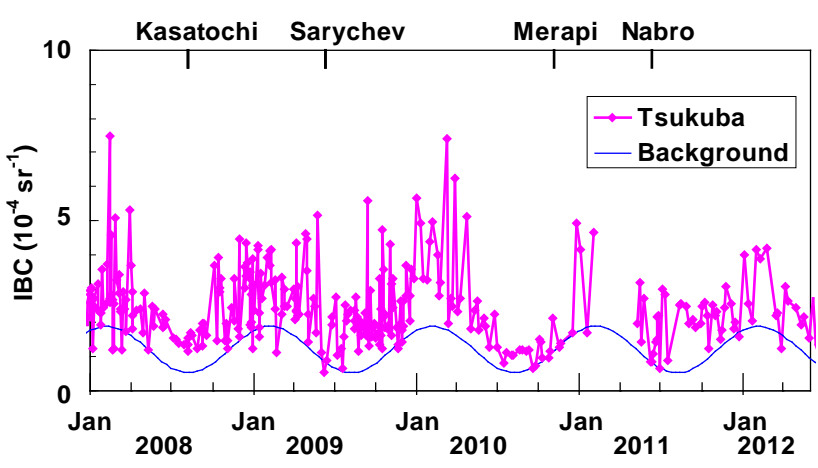

Fig. 8. Temporal variation of IBC from the first tropopause to an altitude of $33 \mathrm{~km}$ (pink solid diamond) over Tsukuba from January 2008 through May 2012. The blue line represents the seasonal variation of the monthly averaged IBC for background stratospheric aerosols observed at Tsukuba during October 1997 through September 2001. The date of each volcanic eruption is shown on the upper horizontal line.

Most IBCs from January 2008 through May 2012 in Fig. 8 were larger than those associated with background aerosols during October 1997 through September 2001. The IBCs increased after the volcanic eruptions of Mt. Kasatochi in August 2008 and Mt. Sarychev Peak in June 2009. The total masses of $\mathrm{SO}_{2}$ from the Kasatochi, Sarychev Peak, and Nabro eruptions were estimated to be $1.6 \mathrm{Tg}, 0.9 \mathrm{Tg}$, and $1.5 \mathrm{Tg}$, respectively (Clarisse et al., 2012). However, the production rate of stratospheric aerosols depends on the amounts of $\mathrm{SO}_{2}$ that are injected into the stratosphere. Before the Kasatochi eruption, the IBC was larger than the background level, an observation consistent with that of Vernier et al. (2011) and possibly due to some other volcanic eruptions in the tropics, including Tavurvur $\left(4.27^{\circ} \mathrm{S}, 152.20^{\circ} \mathrm{E}\right)$ on $7 \mathrm{Oc}-$ tober 2006 and Soufrière Hills $\left(16.72^{\circ} \mathrm{N}, 62.18^{\circ} \mathrm{W}\right)$ on 20 May 2006.

The yearly averaged IBCs over Tsukuba were $2.54 \times 10^{-4} \mathrm{sr}^{-1}, \quad 2.48 \times 10^{-4} \mathrm{sr}^{-1}, \quad 2.45 \times 10^{-4} \mathrm{sr}^{-1}$, and $2.20 \times 10^{-4} \mathrm{sr}^{-1}$ for 2008, 2009, 2010, and 2011, respectively. Therefore the elevations of the IBCs above background level were $1.33 \times 10^{-4} \mathrm{sr}^{-1}, 1.27 \times 10^{-4} \mathrm{sr}^{-1}$, $1.24 \times 10^{-4} \mathrm{sr}^{-1}$, and $0.99 \times 10^{-4} \mathrm{sr}^{-1}$, respectively. The corresponding elevations of the AOTs above background levels were $0.0067,0.0064,0.0062$, and 0.0050 , respectively, for an assumed lidar ratio of $50 \mathrm{sr}$. The corresponding increases of negative radiative forcing (cooling) were roughly $0.17 \mathrm{~W} \mathrm{~m}^{-2}, 0.16 \mathrm{~W} \mathrm{~m}^{-2}, 0.16 \mathrm{~W} \mathrm{~m}^{-2}$, and $0.13 \mathrm{~W} \mathrm{~m}^{-2}$, respectively, based on a conversion factor of $25 \mathrm{~W} \mathrm{~m}^{-2}$ from AOT to radiative forcing (Hansen et al., 2005; Solomon et al., 2011). These values are not small compared to the positive radiative forcing (heating) caused by increases in atmospheric $\mathrm{CO}_{2}$, which has averaged about $0.28 \mathrm{~W} \mathrm{~m}^{-2}$ over the decade since 2000 (Solomon et al., 2011; NOAA, 2012). The average AOT for the 12 months following Pinatubo was 0.13 over Tsukuba, and the Pinatubo aerosol cooling was $3.1 \mathrm{~W} \mathrm{~m}^{-2}$. Recent stratospheric aerosol radiative cooling is about one-twentieth of that caused by the Pinatubo aerosols.

The surface temperature could be lowered by about $0.015-$ $0.025^{\circ} \mathrm{C}$ during the summer if we divide $0.3-0.5^{\circ} \mathrm{C}$ by 20 . It is very difficult to detect such a small change of surface temperature during one year. However, it is noteworthy that increased stratospheric aerosol radiative cooling continued for at least four years, from January 2008 to May 2012. Climate models have been used to simulate climate for a year after volcanic eruptions (Haywood et al., 2010; Kravitz et al., 2011), but multi-year simulations will be necessary to understand the effects of longer term increases in stratospheric aerosols, because, for example, the ocean integrates volcanic radiative cooling and responds over a wide range of time scales (Stenchikov et al., 2009).

We next estimated the influence of the increase in stratospheric aerosols after volcanic eruptions on the $\mathrm{XCO}_{2}$ determined by GOSAT. When the GOSAT $\mathrm{XCO}_{2}$ is retrieved by using the $1.6-\mu \mathrm{m}$ band without taking account of sulfuric acid particles in the stratosphere, the negative bias of $\mathrm{XCO}_{2}$ is estimated to be $0.3 \%(\sim 1 \mathrm{ppm})$ for an AOT of 0.02 at $550 \mathrm{~nm}$ and surface albedo at 0.1 (Ota et al., 2008). It is noteworthy that the largest values of AOT at $532 \mathrm{~nm}$ after the volcanic eruptions of Mt. Sarychev and Mt. Nabro were 
equal to or larger than 0.02. A regional and time-dependent bias of $1 \mathrm{ppm}$ is not small for surface $\mathrm{CO}_{2}$ flux estimation (Rayner and O'Brien, 2001; Takagi et al., 2011). Therefore, it is necessary to take into account the effects of increased stratospheric aerosols for GOSAT $\mathrm{XCO}_{2}$ retrieval (Uchino et al., 2012).

\section{Concluding remarks}

An increase in stratospheric aerosols caused by the volcanic eruption of Mt. Nabro on 12 June 2011 was observed by lidar at Tsukuba and Saga in Japan. The maximum backscattering ratios at $532 \mathrm{~nm}$ were 2.0 at $17.0 \mathrm{~km}$ on 10 July over Tsukuba and 3.6 at $18.2 \mathrm{~km}$ on 23 June over Saga. The maximum integrated backscattering coefficients above the first tropopause height to $33 \mathrm{~km}$ were $4.18 \times 10^{-4} \mathrm{sr}^{-1}$ on 11 February 2012 over Tsukuba and $4.19 \times 10^{-4} \mathrm{sr}^{-1}$ on 23 June 2011 over Saga.

Lidar observational results at Tsukuba from January 2008 through May 2012 revealed increases in stratospheric aerosols after the volcanic eruptions of Mt. Kasatochi in August 2008 and Mt. Sarychev Peak in June 2009. The yearly averaged IBCs at Tsukuba were $2.54 \times 10^{-4} \mathrm{sr}^{-1}$, $2.48 \times 10^{-4} \mathrm{sr}^{-1}, 2.45 \times 10^{-4} \mathrm{sr}^{-1}$, and $2.20 \times 10^{-4} \mathrm{sr}^{-1}$ for 2008, 2009, 2010, and 2011, respectively. These values were about twice the IBC of the background level $\left(1.21 \times 10^{-4} \mathrm{sr}^{-1}\right)$ during the period from 1997 to 2001 at Tsukuba. The elevations of annual average AOT above background levels were about $0.0050-0.0067$ from 2008 to 2011 based on an assumed lidar ratio of $50 \mathrm{sr}$. The negative radiative forcing (cooling) was then roughly 0.13$0.17 \mathrm{~W} \mathrm{~m}^{-2}$ for the same period based on a conversion factor of $25 \mathrm{~W} \mathrm{~m}^{-2}$ from AOT to radiative forcing. These values are not small compared to the radiative heating associated with increases in $\mathrm{CO}_{2}$, about $0.28 \mathrm{~W} \mathrm{~m}^{-2}$ over the decade since 2000 (Solomon et al., 2011; NOAA, 2012). However, because the concentrations of these volcanic aerosols are not always spatially homogeneous, their radiative forcing might be overestimated. The influence of the increase in stratospheric aerosols caused by volcanic eruptions on GOSAT $\mathrm{XCO}_{2}$ retrieval is non-negligible. In the following paper, lidar data over Tsukuba during 2002 through 2007 will be analyzed carefully to find out when the volcanic effect starts for the increase of stratospheric aerosols and to study whether or not the anthropogenic emissions have an impact on the increase.

Acknowledgements. We are grateful to Jiye Zeng for making METEX data available to us. The authors wish to thank the Editor, two anonymous referees, and Mike Fromm for helpful comments. We used the NCEP reanalysis data and radiosonde data measured by the Japan Meteorological Agency. The location and activity report of each volcano were quoted from the Smithsonian Institution Global Volcanism Program (http://www.volcano.si.edu/index.cfm). This research was supported in part by the Environment Research and Technology Development Fund (A-1102) of the Ministry of the Environment, Japan.

Edited by: G. Vaughan

\section{References}

Bitar, L., Duck, T. J., Kristiansen, N. I., Stohl, A., and Beauchamp, S.: Lidar observations of Kasatochi volcano aerosols in the troposphere and stratosphere, J. Geophys. Res., 115, D00L13, doi:10.1029/2009JD013650, 2010.

Bluth, G. J. S., Doiron, S. D., Schnetzler, C. C., Krueger, A. J., and Walter, L. S.: Global tracking of the $\mathrm{SO}_{2}$ clouds from the June, 1991 Mount Pinatubo eruptions, Geophys. Res. Lett., 19, 151154, doi:10.1029/91GL02792, 1992.

Bourassa, A. E., Robock, A., Randell, W. J., Deshler, T., Rieger, L. A., Lloyd, N. D., Llewellyn, E. J., and Degenstein, D. A.: Large volcanic aerosol load in the stratosphere linked to Asian monsoon transport, Science, 337, 78-81, doi:10.1126/science.1219371, 2012.

Clarisse, L., Hurtmans, D., Clerbaux, C., Hadji-Lazaro, J., Ngadi, Y., and Coheur, P.-F.: Retrieval of sulphur dioxide from the infrared atmospheric sounding interferometer (IASI), Atmos. Meas. Tech., 5, 581-594, doi:10.5194/amt-5-581-2012, 2012.

Deshler, T., Anderson-Sprecher, R., Jäger, H., Barnes, J., Hofmann, D. J., Clemesha, B., Simonich, D., Osborn, M., Grainger, R. G., and Godin-Beekmann, S.: Trends in the nonvolcanic component of stratospheric aerosol over the period 1971-2004, J. Geophys. Res., 111, D01201, doi:10.1029/2005JD006089, 2006.

Fernald, F. G.: Analysis of atmospheric lidar observations: some comments. Appl. Opt., 23, 652-653, doi:10.1364/AO.23.000652, 1984.

Hansen, J., Sato, M., Ruedy, R., Lacis, A., Asamoah, K., Borenstein, S., Brown, E., Cairns, B., Caliri, G., Campbell, M., Curran, B., de Castro, S., Druyan, L., Fox, M., Johnson, C., Lerner, J., McCormick, M. P., Miller, R., Minnis, P., Morrison, A., Pandolfo, L., Ramberran, I., Zaucker, F., Robinson, M., Russell, P., Shah, K., Stone, P., Tegen, I., Thomason, L., Wilder, J., and Wilson, H.: A Pinatubo climate modeling investigation, in: The Mount Pinatubo Eruption Effects on the Atmosphere and Climate, NATO ASI Ser., vol. I 42, edited by: Fiocco, G., Fua, D., and Visconti, G., Springer-Verlag, Berlin Heidelberg, 233-272, 1996.

Hansen, J., Sato, M., Ruedy, R., Nazarenko, L., Lacis, A., Schmidt, G. A., Russell, G., Aleinov, I., Bauer, M., Bauer, S., Bell, N., Cairns, B., Canuto, V., Chandler, M., Cheng, Y., Del Genio, A., Faluvegi, G., Fleming, E., Friend, A., Hall, T., Jackman, C., Kelley, M., Kiang, N., Koch, D., Lean, J., Lerner, J., Lo, K., Menon, S., Miller, R., Minnis, P., Novakov, T., Oinas, V., Perlwitz, J., Perlwitz, J., Rind, D., Romanou, A., Shindell, D., Stone, P., Sun, S., Tausnev, N., Thresher, D., Wielicki, B., Wong, T., Yao, M., and Zhang, S.: Efficacy of climate forcings, J. Geophys. Res., 110, D18104, doi:10.1029/2005JD005776, 2005.

Haywood, J. M., Jones, A., Clarisse, L., Bourassa, A., Barnes, J., Telford, P., Bellouin, N., Boucher, O., Agnew, P., Clerbaux, C., Coheur, P., Degenstein, D., and Braesicke, P.: Observations of the eruption of the Sarychev volcano and simulations using the HadGEM2 climate model, J. Geophys. Res., 115, D21212, doi:10.1029/2010JD014447, 2010. 
Hofmann, D. J., Oltmans, S. J., Komhyr, W. D., Harris, J. M., Lathrop, J. A., Langford, A. O., Deshler, T., Jhonson, B. J., Torres, A., and Matthews, W. A.: Ozone loss in the lower stratosphere over the United States in 1992-1993: evidence for heterogeneous chemistry on the Pinatubo aerosol, Geophys. Res. Lett., 21, 6568, doi:10.1029/93GL02526, 1994.

Hofmann, D., Barnes, J., O’Neill, M., Trudeau, M., and Neely, R.: Increase in background stratospheric aerosol observed with lidar at Mauna Loa Observatory and Boulder, Colorado, Geophys. Res. Lett., 36, L15808, doi:10.1029/2009GL039008, 2009.

Jäger, H. and Deshler, T.: Lidar backscatter to extinction, mass and area conversions for stratospheric aerosols based on midlatitude balloonborne size distribution measurements, Geophys. Res. Lett., 29, 1929, doi:10.1029/2002GL015609, 2002.

Jäger, H. and Deshler, T.: Correction to "Lidar backscatter to extinction, mass and area conversions for stratospheric aerosols based on midlatitude balloonborne size distribution measurements", Geophys. Res. Lett., 30, 1382, doi:10.1029/2003GL017189, 2003.

Jäger, H., Uchino, O., Nagai, T., Fujimoto, T., Freudenthaler, V., and Homburg, F.: Ground-based remote sensing of the decay of the Pinatubo eruption cloud at three Northern Hemisphere sites, Geophys. Res. Lett., 22, 607-610, doi:10.1029/95GL00054, 1995.

Kalnay, E., Kanamitsu, M., Kistler, R., Collins, W., Deaven, D., Gandin, L., Iredell, M., Saha, S., White, G., Woollen, J., Zhu, Y., Chelliah, M., Ebisuzaki, W., Higgins, W., Janowiak, J., Mo, K. C., Ropelewski, C., Wang, J., Leetmaa, A., Reynolds, R., Jenne, R., and Joseph, D.: The NCEP/NCAR 40-year reanalysis project, B. Am. Meteor. Soc., 77, 437-471, 1996.

Kawamata, M., Yamada, S., Kudoh, T., and Takano, K.: Atmospheric temperature variation after the $1991 \mathrm{Mt}$. Pinatubo eruption, J. Meteor. Soc. Jpn., 70, 1161-1166, 1992.

Kodera, K.: Influence of volcanic eruptions on the troposphere through stratospheric dynamical processes in the Northern Hemisphere winter, J. Geophys. Res., 99, 1273-1282, doi:10.1029/93JD02731, 1994.

Kondo, Y., Zhao, Y., Uchino, O., Nagai, T., Fujimoto, T., Itabe, T., Mizutani, K., and Shibata, T.: Stratospheric ozone changes at $43^{\circ} \mathrm{N}$ and $36^{\circ} \mathrm{N}$ over Japan between 1991 and 1994, Geophys. Res. Lett., 22, 3223-3226, doi:10.1029/95GL03180, 1995.

Kravitz, B., Robock, A., Bourassa, A., Deshler, T., Wu, D., Mattis, I., Finger, F., Hoffmann, A., Ritter, C., Bitar, L., Duck, T. J., and Barnes, J. E.: Simulation and observations of stratospheric aerosols from the 2009 Sarychev volcanic eruption, J. Geophys. Res., 116, D18211, doi:10.1029/2010JD015501, 2011.

Morino, I., Uchino, O., Inoue, M., Yoshida, Y., Yokota, T., Wennberg, P. O., Toon, G. C., Wunch, D., Roehl, C. M., Notholt, J., Warneke, T., Messerschmidt, J., Griffith, D. W. T., Deutscher, N. M., Sherlock, V., Connor, B., Robinson, J., Sussmann, R., and Rettinger, M.: Preliminary validation of column-averaged volume mixing ratios of carbon dioxide and methane retrieved from GOSAT short-wavelength infrared spectra, Atmos. Meas. Tech., 4, 1061-1076, doi:10.5194/amt-4-1061-2011, 2011.

Nagai, T., Uchino, O., Fujimoto, T., Sai, Y., Tamashiro, K., Nomura, R., and Sunagawa, T.: Lidar observation of the stratospheric aerosol layer over Okinawa, Japan, after the Mt. Pinatubo volcanic eruption, J. Meteor. Soc. Jpn., 71, 749-755, 1993.
Nagai, T., Liley, B., Sakai, T., Shibata, T., and Uchino, O.: PostPinatubo evolution and subsequent trend of the stratospheric aerosol layer observed by mid-latitude lidars in both hemispheres, SOLA, 6, 69-72, doi:10.2151/sola.2010-018, 2010.

NASA: Earth Observatory, available at: http://earthobservatory. nasa.gov/NaturalHazards, last access: July 2012.

NOAA: The NOAA Annual Greenhouse Gas Index (AGGI), available at: http://www.esrl.noaa.gov/gmd/aggi/, last access: July 2012.

O’Neil, N. T., Perro, C., Saha, A., Lesins, G., Duck, T. J., Eloranta, E. W., Nott, G. J., Hoffman, A., Karumudi, M. L., Ritter, C., Bourassa, A., Abboud, I., Carn, S. A., and Savastiouk, V.: Properties of Sarychev sulphate aerosols over the Arctic, J. Geophys. Res., 117, D04203, doi:10.1029/2011JD016838, 2012.

Ota, Y., Yoshida, Y., and Yokota, T.: Study of retrieving column amount of carbon dioxide from satellite-based near-infrared observation of solar scattered light in clear sky condition-error estimation and optimization of vertical pressure grid (in Japanese), J. Remote Sens. Soc. Jpn., 28, 152-160, 2008.

Rayner, P. J. and O'Brien, D. M.: The utility of remotely sensed $\mathrm{CO}_{2}$ concentration data in surface source inversions, Geophys. Res. Lett., 28, 175-178, doi:10.1029/2000GL011912, 2001.

Read, W. G., Froidevaux, L., and Waters, J. W.: Microwave limb sounder measurement of stratospheric $\mathrm{SO}_{2}$ from the Mt. Pinatubo Volcano, Geophys. Res. Lett., 20, 1299-1302, doi:10.1029/93GL00831, 1993.

Robock, A. and Mao, J.: The volcanic signal in surface temperature observations, J. Clim., 8, 1086-1103, 1995.

Sakai, T., Nagai, T., Nakazato, M., Mano, Y., and Matsumura, T.: Ice clouds and Asian dust studied with lidar measurements of particle extinction-to-backscatter ratio, particle depolarization, and water-vapor mixing ratio over Tsukuba, Appl. Opt., 42, 7103-7116, doi:10.1364/AO.42.007103, 2003.

Sakashita, T., Suzuki, K., Adachi, K., and Kikuchi, Y.: Stratospheric aerosols of volcanic origin observed over the Atmospheric Environment Observatory (in Japanese), Tenki, 56, 549-553, 2009.

Smithsonian Institution: Global Volcanism Program, available at: http://www.volcano.si.edu/world/volcano.cfm, last access: July 2012.

Solomon, S., Portmann, R. W., Garcia, R. R., Thomason, L. W., Poole, L. R., and McCormick, M. P.: The role of aerosol variations in anthropogenic ozone depletion at northern midlatitudes, J. Geophys. Res., 101, 6713-6727, doi:10.1029/95JD03353, 1996.

Solomon, S., Daniel, J. S., Neely III, R. R., Vernier, J.-P., Dutton, E. G., and Thomason, L. W.: The persistently variable "background" stratospheric aerosol layer and global climate change, Science, 333, 866-870, doi:10.1126/science.1206027, 2011.

Stenchikov, G., Delworth, T. L., Ramaswamy, V., Stouffer, R. J., Wittenberg, A., and Zeng, F.: Volcanic signals in oceans, J. Geophys. Res., 114, D16104, doi:10.1029/2008JD011673, 2009.

Takagi, H., Saeki, T., Oda, T., Saito, M., Valsala, V., Belikov, D., Saito, R., Yoshida, Y., Morino, I., Uchino, O., Andres, R. J., Yokota, T., and Maksyutov, S.: On the benefit of GOSAT observations to the estimation of regional $\mathrm{CO}_{2}$ fluxes, SOLA, 161164, doi:10.2151/sola.2011-041, 2011.

Uchino, O.: Scientific results of the EPIC projects, in : The Mount Pinatubo Eruption Effects on the Atmosphere and Climate, NATO ASI Ser., vol. I 42, edited by: Fiocco, G., Fua, D., and 
Visconti, G., Springer-Verlag, Berlin Heidelberg, 127-139, 1996. Uchino, O., Nagai, T., Fujimoto, T., Matthews, W. A., and Orange, J.: Extensive lidar observations of the Pinatubo aerosol layers at Tsukuba $\left(36.1^{\circ} \mathrm{N}\right)$, Naha $\left(26.2^{\circ} \mathrm{N}\right)$, Japan and Lauder $\left(45.0^{\circ} \mathrm{S}\right)$, New Zealand, Geophys. Res. Lett., 22, 57-60, doi:10.1029/94GL02735, 1995.

Uchino, O., Sakai, T., Nagai, T., Sakashita, T., Suzuki, K., Shibata, T., Morino, I., and Yokota, T.: Lidar observation of stratospheric aerosols increased from the 2009 Mount Sarychev volcanic eruption (in Japanese), J. Remote Sens. Soc. Jpn., 30, 149-156, 2010.

Uchino, O., Kikuchi, N., Sakai, T., Morino, I., Yoshida, Y., Nagai, T., Shimizu, A., Shibata, T., Yamazaki, A., Uchiyama, A., Kikuchi, N., Oshchepkov, S., Bril, A., and Yokota, T.: Influence of aerosols and thin cirrus clouds on the GOSAT-observed $\mathrm{CO}_{2}$ : a case study over Tsukuba, Atmos. Chem. Phys., 12, 3393-3404, doi:10.5194/acp-12-3393-2012, 2012.

US Committee on Extension of the Standard Atmosphere: US Standard Atmosphere, 1976, US Government Printing Office, Washington, DC, USA, 1976.
Vernier, J.-P., Thomason, L. W., Pommereau, J.-P., Bourassa, A., Pelon, J., Garnier, A., Hauchecorne, A., Blanot, L., Trepte, C., Degenstein, D., and Vargas, F.: Major influence of tropical volcanic eruptions on the stratospheric aerosol layer during the last decade, Geophys. Res. Lett., 38, L12807, doi:10.1029/2011GL047563, 2011.

WMO: Scientific Assessment of Ozone Depletion: 1994, World Meteorological Organization Global Ozone Research and Monitoring Project-Report No. 37, Geneva, 1995.

Wu, P.-M., Okada, K., Tanaka, T., Sasaki, T., Nagai, T., Fujimoto, T., and Uchino, O.: Balloon observation of stratospheric aerosols over Tsukuba, Japan Two years after the Pinatubo volcanic eruption, J. Meteor. Soc. Jpn., 72, 475-480, 1994.

Yoshida, Y., Ota, Y., Eguchi, N., Kikuchi, N., Nobuta, K., Tran, H., Morino, I., and Yokota, T.: Retrieval algorithm for $\mathrm{CO}_{2}$ and $\mathrm{CH}_{4}$ column abundances from short-wavelength infrared spectral observations by the Greenhouse gases observing satellite, Atmos. Meas. Tech., 4, 717-734, doi:10.5194/amt-4-717-2011, 2011. 